\title{
Social Philantropy in Oral Tradition of Multicultural Society in West Bali as an Effort to Build Inclusive Civilization
}

\author{
Ivanka Angelina Dheyanita Prasada ${ }^{1}$, Putu Sulistyawati ${ }^{2}$, Luh Ayu Martasari ${ }^{3}$ \\ \{prasadadheya@gmail.com¹,putusulistya16@gmail.com², ayumartasr@gmail.com³ \\ Universitas Pendidikan Ganesha, Indonesia ${ }^{123}$
}

\begin{abstract}
This study examines the notion of social philanthropy contained in the oral tradition of multicultural societies in West Bali. This study seeks to explore the values of local wisdom in which it shows a symbolic interaction that is thick with historical nuances. Indonesia as a forum for diversity has the potential to experience vertical and horizontal conflicts. If it is not managed properly, diversity will lead to social disintegration. Therefore, inclusive values are needed to build the adaptive civilization of a plural Indonesian nation. This research offers a perspective on the oral traditions of a society that was born based on the similarities and goals of life as an entity formed by history. This study uses a qualitative research method coupled with three disciplines, namely the science of history which helps explain the origin of communities through the study of archives and documents. Sociological studies help document people's social interactions. Meanwhile, the anthropological approach helps ethnographic research. The results of this study illustrate that oral traditions formed through past agreements tend to be able to become the social glue of multicultural societies in West Bali. This research concludes that social philanthropy is a historical and cultural trend of a multicultural society in West Bali which is formed based on the same fate and purpose in life.
\end{abstract}

Keywords: inclusive; multicultural; philanthropy; tradition

\section{Introduction}

In recent times, concerns about the decadence of national and state life have emerged in a number of cases. The values of nationalism in the life of society, nation and state in Indonesia are being disturbed by issues related to SARA (ethnicity, religion, race, between groups), terrorism, radicalism, intolerance and identity politics, which ultimately lead to the disintegration of the nation[1][2]. The problem of national disintegration and the disturbance of the values of unity is more caused by the development of narrow thoughts such as the strengthening of identity politics and intolerance [3].

Oral traditions that live and develop in a multiethnic and multi-religious society in West Bali have similarities with Pancasila as the consensus of the past. By linking various national phenomena recently such as the strengthening of ethnic sentiments and religious primordialism, 
efforts to explore inclusive values in local elements, especially with historical nuances, need to be done[4][5]. Apart from being an effort to strengthen the national identity as well as to provide confidence about a sense of self which is Bhineka Tunggal Ika so that foreign understandings that try to tear the national fabric called Indonesia can be avoided [6].

\section{Method}

This study used a qualitative research design. Conducted using an ethnographic study design combined with historical and sociological approaches by making the social community formed by Dutch colonial plantation workers since the second decade of the XX century (1918) as the research subject. They consist of various ethnicities such as Madurese, Javanese, Bugis and Balinese. Research with an ethnographic study approach for the above purposes requires the researcher to be directly involved in the research arena to make observations, in-depth interviews, and discussions, as well as study historical documents.

\section{Result and Discussion}

Before becoming a settlement, the West Bali area was an area dominated by forests, savanna and steppes. Towards the nineteenth century, European foreign private parties wishing to open plantations in this area had difficulty getting workers from other areas of Bali compared to plantations in Java, so they brought workers from Madura and Java[2]. The workers from south Bali are generally brought in only at harvest time, because most of the workers are casual and not on a contract basis. Meanwhile, the Javanese and Madurese workers got tougher tasks, namely clearing land, including digging soil and ripping forests. Female workers generally receive lighter shares, such as weeding crops and sowing seeds. After harvesting, workers from Bali as casual laborers will return to their home areas, while workers from Madura and Java who get tougher jobs make settlements and settle permanently around plantation areas[7]. The first settlement of the Madurese when Sumberklampok village was opened for coconut plantations in 1918 was carried out in the name of A. Willem Remmert who brought 65 forest furniture from the island of Sapudi, Madura. They are the first generation of Madurese in Sumberklampok village. Meanwhile, the Javanese established settlements in different plantation locations but were still within the same village area[8].

Massive East Balinese migration to West Bali began in 1963 when Mount Agung erupted. The area, which is still empty of population, is an alternative destination for migration. The arrival of the southern Balinese people only started in the mid-1980s in line with the need for labor on plantation lands[9], in Sumberklampok village whose concession rights were transferred to PT Dharmajati and CV. Margarana. The placement of the southern Balinese people began during the leadership of the Governor of Bali, Anak Agung Bagus Sutedja. He borrowed the Sumberklampok plantation land covering an area of approximately 50 hectares for 89 farmer family heads in 1962 . However, not having had the chance to issue a circular5 to recall the 89 farmer families, the traces of it disappeared along with the bloody murder of 1965/1966. There were allegations that they were members of the Barisan Tani Indonesia (BTI), an organization that was said to be affiliated with the Indonesian Communist Party (PKI)[2].

The Dutch Colonial Agrarian Law of 1870 which was in effect in Java was then implemented also in areas outside Java in 1875. The starting point of this Agrarian Law is the statement of public land ownership by citizens (domein verklaring). All land is declared to be owned by the state, unless other parties such as the king state otherwise with certain reasons and evidence. 
The Dutch government can lease agricultural lands that are not demanded by other parties to plantations and European capital owners for a long period of time, namely 75-99 years, 7 which also includes a statement of ownership of land ownership by the government and a prohibition on transferring of agricultural lands[10]. by indigenous people to foreigners who prevailed in Bali Dutch influence officially entered Buleleng after the conquest in 1849. The Jembrana area which was previously a conquest of Buleleng automatically became Dutch subordinates as well. Dutch influence expanded even more after a resident assistant was placed in Buleleng in 1885 and a controloeur in Jembrana in 1856[11]. The first lease of land in Bali was carried out by I Gusti Made Pasekan10, Regent Jembrana in 1860 to L.G.G.R. de Mey van Streefkerk, a clerk in Banyuwangi with a rental payment of $\mathrm{f} 1500$ per year and transactions written in palm leaves. Geographically, the locations of Jembrana and Buleleng are very advantageous in the Balinese economy. This area covers the west coast plains to the hilly plains, extending from the middle of Bali's southwest coast to the mountains. At that time, Resident of Bali and Lombok, F.A Liefricnk, rejected the request to open a plantation in southern Bali because he would urge wet farming in the form of rice. The solution is to make West Bali and northern Bali as private European plantation land. A suitable plant to be cultivated in this area is coconut, which is suitable to grow everywhere in Bali, especially in coastal areas. In the late 19th and early 20th centuries, the need for coconut (copra) was increasing for export, especially to Singapore[12].

In the case of former Dutch colonial plantation workers in West Bali, who consisted of three different ethnicities, namely Balinese, Madurese and Javanese, past self-records did not become the domination of one group alone[13]. They have consciously registered their existence formally since 1967 when the administrative village was first formed. This can be seen in the short chronicle. The aim is clear, namely to legitimize the origin that they and their descendants are the legal heirs to the land they occupy, even though in reality until now their status is only land use rights[14]. Although the formal existence is in the form of a physical record that was only legalized in 1967, Babad Cendek as the idea of social integration of the three ethnic West Balinese inhabitants has existed since the opening of the first plantation in Bali in the second decade of the twentieth century. This is reflected in the social behavior of the community that shows respect, such as the tradition of ngejot, metulungan. The problem is that the integrative attitude is not as fluid as contemporary Balinese society, but still maintains its social segregation. This is possible, because the settlements are built using the collect model. This means that one ethnicity with another ethnic group establishes separate settlements based on ethnic groups and religions[15]. This condition was also supported by the colonial policy in placing the settlements of each ethnic group according to the work specialization. Misnawi (55 years), one of the Madurese figures revealed that the short babad becomes a kind of inter-ethnic social glue that can reduce social tensions. The chronicle has also become a force capable of uniting the local population when dealing with the state. Together, they used the story in the babad as a reference to explain the position and rights of the land where they were born. Putu Artana (45 years), the head of the village of Sumberklampok for two periods (2002-2012) explained that through babad cendek, the sense of ownership was fostered and formed because their ancestors besides being Dutch plantation workers had also built the village. They were already buried and may have become ancestors who would have stayed behind to watch over the village from another realm. Not paying attention to every inch of village land is the same as inviting danger in the form of abstract sanctions such as kepongor. Therefore, the land struggle which is legitimized by babad cendek as a past agreement must be carried out and realized. 


\section{Conclusion}

Both vertically and horizontally, the oral tradition in the form of Babad Cendek becomes the source of identity and primary reference to the past about one's existence. Identity is an important means of legitimacy that the people of West Bali have the right to space. Oral tradition has also become a social glue capable of dissolving ethnic and religious boundaries. This is shown through socio-cultural expressions in the form of certain actions that reflect tolerance. The similarity of fate and the existence of the same aspirations in the future also strengthen the sense of belonging.

\section{References}

[1] Y. Rachmawati, C.-H. Lu, H.-H. Chen, O. Setiasih, and L. Kurniawati, "Implementing instructional system design between taiwan and indonesia via online teaching," Int. J. Educ., vol. 8, no. 1, pp. 64-73, 2014.

[2] I Gde Parimartha, "Karakter bangsa dan aktualisasinya dalam kehidupan masyarakat bali," Forum Arkeol., vol. 25, no. 2, pp. 95-106, 2018.

[3] G. . Gunnarsson, G. . Finnbogason, H. Ragnarsdottir, and H. Jonsdottir, "Frendship, diversity and fear: young people's life views and life values in a multicultural society," Nord. J. Humanit. Soc. Sci. Educ., vol. 15, no. 2, pp. 94-113, 2015.

[4] R. Čičak-Chand, "Multicultural policies and interethnic relations: canada," Migr. i etnicke teme, vol. 21, no. 1-2, pp. 55-68, 2005.

[5] J. Bertrand, "Indonesia's quasi-federalist approach: Accommodation amid strong integrationist tendencies," Int. J. Const. Law, vol. 5, no. 4, pp. 576-605, 2007.

[6] I. B. S. Saitya, I. K. S. Arimbawa, A. W. Gaduh, P. E. Suryanti, and N. P. E. Rahayu, "Multiculturalism in hindu religious education perspective," Vidyottama sanatana Int. J. hindu Sci. Relig. Stud., vol. 4, no. 1, pp. 110-118, 20020.

[7] U. Yusufa, "Pendidikan multikulturalisme dan hak asasi manusia di indonesia," Insa. J. Pemikir. Altern. kependidikan, vol. 15, no. 3, pp. 441-452, 2018.

[8] U. Chafidhi, W. A. Rais, and D. Purnanto, "Verbal and non-verbal expression in javanese language of the coastal community in banjar kemuning village, sidoarjo," Int. J. Multicult. multireligious Underst., vol. 6, no. 6, pp. 185-194, 2019.

[9] U. Bosma, "Commodification and Slavery in the Nineteenth-Century Indonesian Archipelago,” J. Soc. Hist., vol. 54, no. 1, pp. 109-124, 2020.

[10] T. Chakraborty and V. Rossum, "Slave Trade and Slavery in Asia-New Perspectives," $J$. Soc. Hist., vol. 54, no. 1, pp. 1-14, 2020.

[11] I. W. Winaja, I. W. S. W. Prabawa, and P. R. Pertiwi, "Acculturation and its effects on the religious and ethnic values of bali's catur village community," J. Soc. Stud. Educ. Res., vol. 10, no. 3, pp. 249-275, 2019.

[12] B. B. Utomo, "Majapahit dalam lintas pelayaran dan perdagangan nusantara," Berk. Arkeol., vol. 29, no. 2, 2009.

[13] Gusti Ayu Armini, "Toleransi masyarakat multi etnis dan multiagama dalam organisasi subak di bali," Patanjala J. Penelit. Sej. dan budaya, vol. 5, no. 1, pp. 38-52, 2017.

[14] Z. Zulfakar, "Continuous education for all," Int. J. Multicult. multireligious Underst., vol. 7, no. 7, pp. 297-307, 2020. 
[15] I Made Purna, "Kearifan lokal masyarakat desa mbawa dalam mewujudkan toleransi beragama," J. Pendidik. dan Kebud., vol. 1, no. 2, pp. 261-277, 2016. 